УДК 81'25-13'373.46:347

\title{
TRANSLATION METHODS \\ IN CIVIL LAW TERMS: A CASE STUDY
}

\author{
Anna Kizińska \\ University of Warsaw \\ 4, Szturmowa St., Warsaw, Poland, 02-678 \\ anna.kizinska@uw.edu.pl.
}

The present paper presents Polish and British incongruent terms referring to civil law (family law) and constitutes an attempt to assess the adequacy of the English equivalents of the analysed Polish terms. The terms appear in the last part of the Family and Guardianship Code under the title Opieka i kuratela and are listed in the subject index of the Code. The equivalents in question appear in the Polish Family and Guardianship Code translation into English and in bilingual Polish- English dictionaries. The definitions of the Polish civil law terms are presented beginning with the definitions of a term and equivalence. The definitions cited below of the Polish terms appear in an up-to-date commentary on the Polish Family and Guardianship Code. In the process of assessing the adequacy of their equivalents, the appearance of equivalents in the sources of British law has been checked, and the legal definitions of equivalents have been presented if needed. The translation methods applied while forming the equivalents have been determined, which has revealed the dominant role of the functional equivalent method in translating incongruent family law terms.

Keywords: equivalence, family law, term, functional equivalent, incongruity

Introduction. The present paper aims to present Polish and British incongruent terms referring to civil law (family law) and makes an attempt to assess the adequacy of the English equivalents of the Polish terms analysed. The Polish terms under analysis are kuratela, kurator, opieka and zasady wspólzycia społecznego. The equivalents discussed come from four bilingual legal dictionaries and one translation of the Polish Family and Guardianship Code into English. In the process of assessing the adequacy of their equivalents, the appearance of equivalents in the sources of British law is to be checked, and the legal definitions of equivalents are to be cited. Finally, the translation methods applied while forming the equivalents are to be determined.

Theoretical background. The concept of equivalence is closely connected with the phenomenon of incongruity of terms, i.e. non-coincidence of their semantic fields. Legal terminology characteristic of different legal systems is to a large extent conceptually incongruent $[11$, p. 278]. "Because of the inherent incongruence of the terminology of different legal systems, natural equivalents of the target legal system that are identical to their source terms at the conceptual level cannot be used but the closest natural equivalent (the equivalent that most accurately conveys the legal sense of the source term and leads to desired results) can be chosen" [12, p. 234-235].

(C) A. Kizińska, 2017 
Furthermore, Hejwowski states that the degree of equivalence does not refer only to specialised disciplines determined culturally [1: 32]. Moreover, Jopek-Bosiacka [3, p. 47] states that the multitude of legal systems is often the source of non-equivalence of concepts or noncoincidence of semantic fields of terms.

The term functional equivalent is defined in translation studies by various definitions (e.g. Reiss and Vermeer [10]). In this paper I follow the definition by Šarčević, id est, "a term designating a concept or institution of the target legal system having the same function as a particular concept of the source legal system" [12, p. 236].

At the end of the research the translation methods used while forming the analysed equivalents are to be determined. The translation method in this paper is understood according to its definition by Hejwowski, who explains it not only as a given type of action undertaken during the translation process but also given translation solutions the implementation of which is the target text [1,p. 76].

As far as the paper is concerned it should be emphasised that the United Kingdom of Great Britain and Northern Ireland has no unified legal system. England and Wales have one common legal system, whereas Scotland and Northern Ireland have separate legal systems. In this paper the terms used to name legal institutions of the legal systems of England, Wales, Scotland and Northern Ireland are called British legal system terms.

Methods. The terms under analysis all appear in the last part of the Family and Guardianship Code under the title Opieka i kuratela as well as being listed in the subject index of the Code. The terms in question are all assumed to be terms in accordance with the following definition of a term by Lukszyn and Zamrzer: "a word (a phrase) of a conventionally determined, strictly defined conceptual structure, as a rule monosemic and uninterpretable, of an emotional character, able to create systems" [6, p. 9]. What is more, the terms analysed constitute legal terms according to the division of terms by Morawski (7, p. 187), who distinguishes legal terms and actual terms. A legal term is a term occurring in teksty prawne, all the application criteria of which are defined by law and expressed by legal definitions classical or partial. By contrast, an actual term is a term the application criteria of which are not formulated in a tekst prawny [7, p. 187].

The first stage of the research involves citing the definitions of the Polish legal term analysed and listing its equivalents suggested in The Family and Guardianship Code [21] translation into English and the four most popular bilingual Polish-English specialist legal dictionaries. Next, if any appear in legal dictionaries, the definitions of the suggested English equivalents are presented. The cited definitions of the Polish terms come from an up-to-date commentary on the Polish Code, whereas the definitions of English terms appear in English law dictionaries. It is vital to compare the definitions of the Polish terms and their English equivalents in order to state whether the equivalents constitute functional equivalents of the terms (if the functions of the institutions to which a given term and equivalent refer are the same).

The aim of the second stage of the research is to check whether or not the equivalents under analysis appear in the texts of the sources of British law. The texts of the sources of British law are the texts of statutes available in the legislation.gov.uk database which "carries most types of legislation and their accompanying explanatory documents" [25]. The third stage of research involves the presentation of translation methods used while creating the English equivalents of the Polish terms under analysis. 
Results and discussion. Presented below are the equivalents of the term kuratela.

\begin{tabular}{|l|l|}
\hline equivalent(s) & Source \\
\hline curatorship & Jaślan (bilingual dictionary) (15) \\
\hline curatorship, guardianship & Myrczek (bilingual dictionary) (17) \\
\hline tutelage, wardship, guardianship & Ożga (bilingual dictionary) (18) \\
\hline ad hoc guardianship, tutelage, wardship & Pieńkos (bilingual dictionary) (19) \\
\hline guardianship & CH Beck (code translation) \\
\hline
\end{tabular}

The Polish term kuratela is defined as a legal institution the aim of which is to provide care for private individuals and bodies corporate that, for various factual or legal reasons, are not able to manage their own affairs [9, p. 1101]. The equivalents guardianship and curatorship appear in the sources of British law, namely the Mental Capacity Act 2005 [23] and the Adults with Incapacity (Scotland) Act [22].

The term guardianship does not appear in A dictionary of law or the Law Student's Dictionary and is not defined in the British sources of law. The term guardian, however, is defined as "one who has the charge of custody of any person or thing" [20] and "one who is formally appointed to look after a child's interests when the parents of the child do not have parental responsibility for him or have died" [13]. Taking into account the above definitions of the Polish term and the term guardian, one may state that the equivalent guardianship presumably constitutes a functional equivalent of the Polish term since both legal institutions (Polish kuratela and British guardianship) have the same function, namely to take legal care of an entity. What is more, the equivalent appears in the sources of British law so it is not a calque. The equivalent curatorship is not accommodated by The Law Student's Dictionary [20] or A Dictionary of Law [13]. However, the term curator, according to its definition, refers to a person "entrusted with the charge of an estate, or with the conduct of a minor who is past the age of pupillarity, or with the management of a lawsuit" [20]. One may conclude that the equivalent "curatorship" constitutes a functional equivalent of the Polish term under discussion as it appears in the sources of British law and the function of the legal institution it names is the same as that of the Polish legal phenomenon.

Another equivalent suggested in one of the legal bilingual dictionaries is wardship. This English word appears in the sources of British law in numerous acts and different contexts showing its slightly different meanings. Furthermore, it is defined in law dictionaries as follows: "the jurisdiction of the High Court to make a child a ward of court and to assume responsibility for its welfare"; simultaneously the term ward of court is understood as "a minor under the care of a guardian, who exercises rights and duties over the child subject to the general control and discretion of the court" and "A minor in respect of whom a wardship order has been made and over whom the court exercises parental rights and duties". Similarly to the above discussed equivalents, it may be concluded that the equivalent "wardship" constitutes a functional equivalent of the Polish term since it appears in the sources of British law and the main function of the legal institution it names is the same as that of the Polish legal institution.

The remaining suggested equivalents, namely tutelage and ad hoc guardianship, are not accommodated in English law dictionaries and do not appear in the sources of British law. The word tutelage is defined in the Longman Dictionary of Contemporary English [16] as "when you are taught or looked after" and "responsibility for someone's education, actions or property", thus the meaning of this term is close to one of the Polish legal terms. The fact that the equivalent does not appear in the sources of British law and has a similar meaning in general English to the Polish term may lead to the conclusion that it has been formed by means of the terminologisation method that involves using in the target text a word or phrase which exists in the target language but is not 
a legal term of the target language. As a result of the application of this method a word or phrase of the target general language becomes a legal term in the target text [5, p. 177]. The equivalent ad hoc guardianship constitutes a descriptive equivalent (with regard to the element $a d$ hoc) and a functional equivalent (with regard to the element guardianship). A descriptive equivalent is understood here as a method "involving replacing a term with a description or definition (...)" [1, p. 82]. The equivalent under discussion emphasises one of the characteristics of the Polish legal institution called kuratela, namely its temporary nature as compared with a similar Polish legal institution called opieka, the characteristic feature of which is its permanent character. The Latin expression ad hoc is defined as "made or happening only for a particular purpose or need, not planned before it happens" [14].

Presented below are the equivalents of the term kurator

\begin{tabular}{|l|l|}
\hline equivalent(s) & Source \\
\hline curator, guardian & Jaślan \\
\hline curator, guardian & Myrczek \\
\hline guardian, tutor & Ożga \\
\hline guardian, tutor & Pieńkos \\
\hline custodian & CH Beck \\
\hline
\end{tabular}

The Polish term kurator has numerous meanings in various law branches, which is why the most popular manner of defining this term in legal doctrine is the presentation of the division of its types with regard to its functions. Kurator is defined in legal course books together with kuratela and thus on the basis of the above-mentioned definition of kuratela the term kurator may be defined as a person who provides care for private individuals and bodies corporate that, for various factual or legal reasons, are not able to manage their own affairs.

The equivalents suggested in bilingual dictionaries and the translation of The Family and Guardianship Code [21] into English (guardian, tutor, curator) numerously occur in the sources of British law. Taking into account the above cited definitions of guardian and curator as well as the Polish term kurator, it may be stated that the equivalents constitute functional equivalents of the Polish term since both legal institutions (Polish and British) have the same function, namely to take legal care of an entity. The last equivalent, tutor, has not been accommodated by the English dictionaries of law and simultaneously it appears in the sources of British law in various meanings and contexts; thus the technique used while forming the equivalent in question is apparentlyelusive.

Presented below are the equivalents of the term opieka

\begin{tabular}{|l|l|}
\hline equivalent(s) & Source \\
\hline care, custody, guardianship & Jaślan \\
\hline care, custody & Myrczek \\
\hline wardship, tutelage (synonym of kuratela) & Ożga \\
\hline wardship, tutelage (synonym of kuratela) & Pieńkos \\
\hline care & CH Beck \\
\hline
\end{tabular}

The Polish term opieka is equivocal [9, p. 1026] but according to Polish family law it means "an institution providing the protection of personal and property interests of minors who, for various reasons, are deprived of parental responsibility and the totally incapacitated" [9, p. 1026]. It should be 
emphasised that the Polish terms kuratela and opieka name two similar but distinct legal institutions [2, p. 418], thus Ożga and Pieńkos [18; 19] should not treat the term opieka as a synonym of kuratela.

As far as the equivalents guardianship and wardship are concerned, it should be stated, on the basis of the above cited definitions, that they constitute functional equivalents of the Polish term opieka as both the Polish and British legal institutions have the same function, namely to take legal care of an entity. Moreover, the research results on the equivalent tutelage (presented above in connection with the term kuratela) also refer to the term opieka.

The equivalent care appears in the sources of British law in numerous meanings. What is more, it is not explicitly defined in English law dictionaries. Its meaning, however, may be deduced from the definition of the term care order which is defined as: "a court order placing a child under the care of a local authority (...) The court has the power to make a court order only when it is satisfied that a child is suffering or likely to suffer significant harm caused by the care (or lack of care) given to it by its parents, or because the child is beyond parental control" [13]. On the basis of the definition cited it may be concluded that the equivalent care is not only a functional equivalent of the Polish term opieka (as both Polish and British legal institutions in question have the same function, which is to provide care of an entity), but also constitutes the most accurate equivalent for the Polish term opieka as it refers to the legal institution which involves care provided for children, is of a permanent character and presumably involves taking care not only of a child's material interests but also its psychological development. In the Polish doctrine the permanent character of opieka and the fact that it involves taking care of a child's psychological development are emphasised [24].

The last suggested equivalent is custody. The equivalent mentioned appears in the sources of British law in various meanings. In A Dictionary of Law it is elucidated as: "Formerly, the bundle of rights and responsibilities that parents (and sometimes others) had in relation to a child. Custody, which featured in various statutes, has now been replaced by the concept of parental responsibility introduced by the Children Act 1989" [13]. As the definition states, the term custody is no longer a term of family law in British law. Current articles confirm the change: "There is no such thing as custody in English law any more. Instead there is the concept of parental responsibility and orders the court can make on various issues." (26) so the terms custody and custodian (suggested above as an equivalent for the Polish term kurator) are inaccurate equivalents and using them may be misleading for their recipients.

Presented below are the equivalents of the term zasady wspótżycia społecznego

\begin{tabular}{|l|l|}
\hline equivalent(s) & Source \\
\hline---- & Jaślan \\
\hline---- & Myrczek \\
\hline principles of social life & Ożga \\
\hline--- & Kozierkiewicz \\
\hline principles of social coexistence & CH Beck \\
\hline
\end{tabular}

The Polish term zasady wspólzycia społecznego is a clausula generalis (an indeterminate phrase that may be interpreted in various ways) and belongs to general civil law matters. In the context of family law zasady wspólżycia społecznego may refer to moral norms including principles of interpersonal behaviour, or moral norms including principles of interpersonal behaviour and social norms [9, p. 2009]. The English equivalents suggested do not appear in dictionaries of law or the sources of British law, so they presumably constitute a calque. The term calque is in this paper defined according to the definition by Kierzkowska. She explains the term calque as a word- 
for-word translation of a given word combination (...)" [4, p. 33]. The equivalents principles of social life and principles of social coexistence reflect the Polish term word after word.

Conclusion. To summarise, the most common translation method used to form equivalents for incongruent terms (concerning opieka and kuratela issues) that appear in bilingual dictionaries and The Code translation into English is a functional equivalent (curatorship, curator, guardianship, guardian, wardship, care custody). Relatively rare methods are terminologisation (tutelage), a descriptive equivalent (ad hoc guardianship) and a calque (principles of social life, principles of social coexistence). Additionally, it may be concluded that the functional equivalent guardian constitutes a recognized translation ("official or the generally accepted translation of any institutional term") defined by Newmark [8, p. 89], as it is an equivalent occurring in all four bilingual dictionaries.

Furthermore, in all dictionaries one functional equivalent for each Polish term under analysis has appeared, in two cases accompanied by a descriptive equivalent or an equivalent formed as a result of terminologisation provided that there has been more than one equivalent suggested in all dictionaries. Moreover, two bilingual dictionaries treat kuratela and opieka as synonyms despite the fact that they denote two distinct Polish family law institutions. It should be emphasised that the suggested terms custody and custodian are inaccurate equivalents as the legal institutions they name are no longer institutions of family law in the UK.

Owing to the fact that the family law terms under analysis come from a civil law legal system and the equivalents suggested are to function in a common law legal system, a translator should possess enhanced knowledge in source and target legal systems to be able to compare the legal institutions denoted by the terms in question and use the most accurate equivalent.

\section{References}

1. Hejwowski K. Kognitywno-komunikacyjna teoria przekładu / K. Hejwowski. - Warszawa : PWN, 2007. - $197 \mathrm{~s}$.

2. Ignatowicz J. Prawo rodzinne / Ignatowicz J., Nazar M. - Warszawa : LexisNexis, 2010. - 432 s.

3. Jopek-Bosiacka A. Przekład prawny i sądowy / A. Jopek-Bosiacka. - Warszawa : PWN, 2008. $253 \mathrm{~s}$.

4. Kierzkowska D. Kodeks Tłumacza Przysięłego / D. Kierzkowska. - Warszawa : TEPIS, 1991. $260 \mathrm{~s}$.

5. Kizińska A. Ekwiwalencja w thumaczeniu tekstów prawnych i prawniczych. Prawo spadkowe / A. Kizińska. - Warszawa : CH Beck, 2015. - 204 s.

6. Lukszyn J. Teoretyczne podstawy terminologii / J. Lukszyn, W. Zmarzer. - Warszawa : Wydział Lingwistyki Stosowanej i Filologii Wschodnio-słowiańskich UW, 2001. - 189 s.

7. Morawski L. O pewnym rozumieniu prawa i faktu oraz o niektórych jego zastosowaniach / L. Morawski // Ruch Prawniczy, Ekonomiczny i Socjologiczny. - 1980. - Nr 1. - S. 185-204.

8. Newmark P. Approaches to Translation / P. Newmark. - Prentice Hall, 1988. - 198 p.

9. Piasecki K. Kodeks rodzinny i opiekuńczy, komentarz / K. Piasecki (ed.). - Warszawa : LexisNexis, 2009. - $1135 \mathrm{~s}$.

10. Reiss K. Grundlegung einer allgemeinen Translationstheorie / K. Reiss, H. Vermeer. - Tübingen : Niemeyer, 1984. - $245 \mathrm{~S}$.

11. Šarčević S. Conceptual dictionaries for translation in the field of law / S. Šarčević // International Journal of Lexicography. - 1989. - vol. 2. - no 4. - P. 277-293.

12. Šarčević S. New Approach to Legal Translation / S. Šarčević. - The Hague / London / Boston : Kluwer Law International, 1997. - 308 p. 


\title{
Sources
}

13. A Dictionary of Law. - Oxford : Oxford University Press, 2003. - 551 p.

14. Cambridge Dictionaries Online. Electronic resource. Mode of access - https://ictionary.cambridge.org/

15. Jaślan J. Słownik terminologii prawniczej i ekonomicznej / J. Jaślan, H. Jaślan. - Warszawa : Wiedza Powszechna, 2015. - $724 \mathrm{~s}$.

16. Longman Dictionary of Contemporary English. - Pearson Education Limited, 2003. 1949 p.

17. Myrczek-Kadłubicka E. Dictionary of Law Terms. English-Polish, Polish-English / E. MyrczekKadłubicka. - Warszawa : C.H. Beck, 2013. -482 p.

18. Ożga E. Słownik terminologii prawniczej, część 1 polsko-angielska / E. Ożga. - Bydgoszcz : Oficyna Wydawnicza Branta, 2001. - 520 s.

19. Pieńkos J. Polsko-angielski słownik prawniczy / J. Pieńkos. - Kraków : Zakamycze, 2002. - 493 s.

20. Penner J. The Law Student's Dictionary / J. Penner. - Oxford : Oxford University Press, 2008 - 336 p.

21. The Family and Guardianship Code. - Warszawa : C.H. Beck, 2010. - 14 p.

22. Adults with Incapacity (Scotland) Act. Electronic resource. Mode of access - www.legislation.gov. uk [Accessed 22 December 2014].

23. Mental Capacity Act, 2005. Electronic resource. Mode of access - www.legislation.gov.uk [Accessed 22 December 2014].

24. Ryńska N. Opieka nie jest kuratelą - jakie są pomiędzy nimi różnice. Electronic resource. Mode of access - http://prawo.gazetaprawna.pl/artykuly/843449,opieka-nie-jest-kuratela-czym-sie-roznia. html [Accessed 22 December 2014].

25. What legislation is held on legislation.gov.uk? Electronic resource. Mode of access -http://www. legislation.gov.uk/help\#aboutLeg [Accessed 22 December 2014].

26. Woelke A. Children. Electronic resource. Mode of access - http://www.alternativefamilylaw.co.uk/ en/children/ [Accessed 22 December 2014].

\section{ПЕРЕКЛАДНІ МЕТОДИ У ТЕРМІНАХ ЦИВІЛЬНОГО ПРАВА: ВИВЧЕННЯ ВИПАДКУ}

\author{
Анна Кізіньска \\ Варшавський університет \\ вул. Штурмова, 4, Варшава, Польщча, 02-678 \\ anna.kizinska@uw.edu.pl.
}

У статті представлено випадки смислової невідповідності термінів цивільного (сімейного) права при зіставленні законодавств Великої Британіііі та Польщі та спробу досягнення відповідностей перекладу таких термінологічних одиниць польською мовою. Зосереджено увагу на текстах останньої частини “Кодексу про сім'ю та опіку” з інвентарним списком термінів та виявах дефініційної еквівалентності у першотекстових, коментарних та довідкових джерелах. Застосовано двоступеневу верифікацію еквівалентності невідповідних термінів у текстових та номенклатурних ресурсах законодавства Британії як першотвору. Переважаючий конструктивізм у досягненні міжмовної еквівалентності невідповідних щодо смислового навантаження понять визнано за перекладацьким методом функційної еквівалентності.

Ключові слова: еквівалентність, сімейне право, термін, функційний еквівалент, невідповідність. 